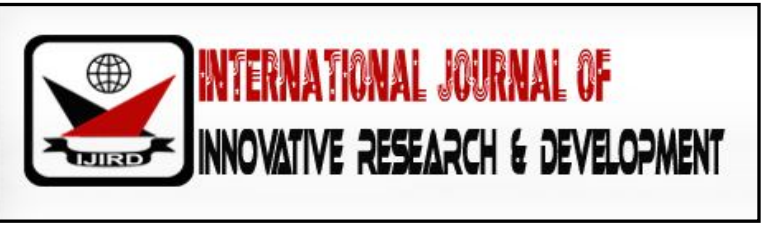

ISSN 2278 - 0211 (Online)

\title{
In-Service Science Teachers View about the Nature of Science and Its Implication for Constructivist Teaching at the Junior High Schools in Ghana
}

\author{
Yin Annafo \\ Tutor, Wesley College of Education, Science Department, Ghana \\ Charles Agyei Amoah \\ Biology Tutor, OLA College of Education, Science Department, Ghana
}

\begin{abstract}
:
The purpose of the study is to investigate in-service science teachers' view about the nature of science and its implication for constructivist teaching at the junior high schools in Ghana. A descriptive survey design was employed. The target population for the study comprised all the public Junior High School science teachers in the Kumasi Metropolis in the Ashanti Region of Ghana. Two science teachers each from one hundred (100) randomly selected public Junior High School (J.H.S.) in the Kumasi Metropolis in the Ashanti region of Ghana were sampled randomly for this study. The main instrument used for the collection of data in this study was the close-ended questionnaire. It was found out that the teachers showed inadequate understanding of the nature and characteristics of scientific knowledge and how this knowledge is generated. Majority of the teachers had a positive belief that science teaching takes place in a constructivist's perspective. It was recommended that teacher education programs should provide teacher trainees with methods and opportunities to learn in order to implement constructivist teaching and learning in their classrooms.
\end{abstract}

Keywords: Constructivist teaching, in-service teachers, beliefs, constructivism

\section{Introduction}

The role of science in the socio-economic development of societies and nations in the world today hardly needs any arguments. It is in view of this role that science education has found a secured place in school curricula of most countries around the world, particularly since the last few decades. However, the kind of science to be taught and how to teach it at different levels has been changing over the last few decades. Modern science curricula in various countries do not solely focus on developing the understanding of science concepts in their students; it embodies a wide variety of goals. For instance, the recent reforms in science, particularly in developed countries, have placed an added emphasis on the development of students' understanding about the 'nature of science' (American Association for the Advancement of Science (AAAS), 1990; National Research Council (NRC), 1996).However, this aspect of science education is yet to take roots in many developing countries such as Ghana.

Some years ago, students in schools and colleges were taught that science was a collection of facts; a fixed body of knowledge; an organized body of knowledge; an absolute truth; agreed upon and objective knowledge (Iqbal, 1998). Such views of science have many consequences both for students as well as teachers. By implication, students develop an understanding that there is no room for new discoveries; and that whatever is known about natural phenomenon is absolute and final. The implication for teaching is that teachers of science have to transmit that fixed body of knowledge to students and students have no other alternative except to learn and memorize what they are told.

Ghana, in spite of her colonial past, still values her cultural heritage. One important part of this cultural heritage is respect for the elderly or leaders and this naturally includes teachers. The Ghanaian classroom atmosphere has been influenced greatly by this tradition making the elderly assume the status of custodians of knowledge. Consequently, the teacher embodies the proverbial "sage on stage". This results in children generally becoming less apt to ask questions or contribute in the classroom, and the teacher is the final authority of knowledge. The concomitant method of instruction for the majority of teachers is the lecture method; delivering knowledge, as it were, into "empty, but willing vessels." 
It must be mentioned, however, that science teaching and learning inherently resist the all-lecture approach, and readily lends itself to practical work. It is very uncommon a practice to find the Ghanaian science teacher engaging students in hands-on activities where facilities are available, and employing the guided-discovery approach in instruction. One would rarely find the science teacher take the students to the school garden to learn science by practice, or going to the nearby stream to collect live specimen for study.

The way science is taught and learned in our schools should greatly be influenced by the meaning and Nature of Science. Science may be defined as the way of learning which involves first-hand experience, inquiry, problem solving, interpretation and communication of findings (Burnie, 2008). It is also the process of obtaining knowledge through observation and experimentation.

From the above, it can be deduced that as humans explore their immediate environment, as active-knowledge searching creatures that transform and interpret experience using developed biological and mental structures, he/ she associates meaning to phenomenon and occurrences that he/ she encounters, and this knowledge so generated through observing, experimenting, analyzing, classifying, manipulating, calculating and others is considered as scientific knowledge.

The recent Junior High School science curriculum in Ghana as seen in many countries however detests "transmission of instruction"; rather emphasis is placed on learner centered activities aimed at developing a scientific way of life through curiosity and investigative habits in the learner.

Teaching and learning methods which emphasize the inquiry method and social constructivism-where learners construct their own knowledge and understandings based on what they already know and the socio-cultural context in which they find themselves has been claimed by most educational analysts to be very suitable for helping pupils develop positive attitudes and process skills through hands-on and minds-on activities (UNESCO, 2005). Though the Ghanaian J.H.S. science curriculum is one that appears to encourage these methodologies to a greater extent, the constructivists and the inquiry methods seem less popular among the Ghanaian J.H.S. science teacher. Teaching is largely by exposition with little opportunities for learners to engage in practical and problem-solving activities, which generate deeper understanding (Anamuah-Mensah et al. 2008).

Commenting on the same issue, Fredua-Kwarteng and Ahia (2005) indicated that in the Junior High Schools in Ghana, students are not taught to view science as a form of knowledge concerned with understanding natural phenomena, leading to both knowledge validation and construction.

\subsection{Statement of the Problem}

Poor performance in science is reported several times among Junior High school students in the chief examiner's report almost every year, in the Basic Education Certificate Examination (Chief examiner's report, 2005-2008). The abysmal performance of Ghanaian grade eight students in Mathematics and Science in TIMSS 2003 and 2007(Anamuah-Mensah, Mereku and Asabere-Ameyaw 2004; Anamuah-Mensah, Mereku and Ampiah 2009) also serves as evidence of the state of science teaching and learning in Ghana. This problem of poor performance indicates failure of students to understand science concepts and skills presented to them in class as well as the failure of science teachers to facilitate student learning. However, one important area that has not received much consideration in the search for causes of students poor performance in science in Ghana has been the science teacher's epistemological beliefs of science teaching and learning. This has necessitated the need to investigate in-service science teachers 'view about the nature of science and its implication for constructivist teaching at the junior high schools in Ghana.

\subsection{Purpose of the Study}

The purpose of the study is to investigate in-service science teachers' view about the nature of science and its implication for constructivist teaching at the junior high schools in Ghana.

\subsection{Research Questions}

- What is the science teachers 'view about the nature of science and its implication for constructivist teaching?

- How do teachers incorporate their beliefs about nature of science in teaching the subject in the contemporary constructivist viewpoint?

\section{Methodology}

A descriptive survey design was employed. The target population for the study comprise all the public Junior High School science teachers in the Kumasi Metropolis in the Ashanti Region of Ghana. Two science teachers each from one hundred (100) randomly selected public Junior High School (J.H.S.) in the Kumasi Metropolis in the Ashanti region of Ghana were sampled randomly for this study. The Kumasi Metropolitan schools comprise one hundred and seventy-one (171) publicJunior High Schools scattered over twenty-two (22) educational circuits in ten (10) sub-metroswitha total of about three hundred and forty-two (342) science teachers.

The main instrument used for the collection of data in this study was the close-ended questionnaire. The items in the questionnaire were in three parts, the first part demanded the personal data of the teachers while the second part was based on the "Nature of scientific knowledge" and it was meant to address the teachers" beliefs about science as a body of knowledge 
and the process of development of scientific knowledge and, cultural and social relevance of science. The third segment was focused mainly on teachers' knowledge about various pedagogical skills and the constructivists teaching. The closed-ended questions type, were designed on a 4-point Likert scale ranging from strongly agree to strongly disagree.

Documents and records were also analyzed.Ninety of the teachers were interviewed randomly to find out their views about the nature of science and its implication for teaching science. Unstructured interview type was used in this regard.

\section{Results/ Findings}

Analysis of data was done research question by research question. The mean scores of values were first calculated and later the overall mean scores. This was done in order to rank the views of the respondents according to items in the questionnaire with respect to the research questions.

The middle value of 2.5 on the 4-point Likert scale used in this study was taken to be the average mean score of the responses by respondents which also represented a "neutral position" in the study (Anderson 2006). This value representing a neutral position was used in this study to indicate a position that respondents neither agree nor disagree with a statement.

A mean value less than the 2.5 indicated a general view of disagreement whiles the mean score greater than the 2.5 also indicated a general view of agreement with the statements.

\begin{tabular}{|r|c|c|c|}
\hline & $\mathbf{N}$ & Mean & Std. Deviation \\
\hline 1. Science involves firsthand experience, inquiry, and problem solving. & 200 & 3.25 & .743 \\
\hline 2. Scientific knowledge and explanation in books are always true & 200 & 2.92 & .808 \\
\hline 3. There is scientific knowledge in folklore and myth & 200 & 2.95 & .722 \\
\hline 4. Science as seen in textbooks is the same as real science & 200 & 2.63 & .905 \\
\hline 5. Facts of science do change with time & 200 & 2.48 & 1.012 \\
\hline 6. Science can best be taught from textbooks and worksheets & 200 & 2.22 & .871 \\
\hline The best way to learn science is memorizing facts and principles & 200 & 1.86 & .827 \\
\hline 8. Scientific knowledge changes with time & 200 & 2.86 & .886 \\
\hline 9. Science is a human construct/ effort & 200 & 3.13 & .862 \\
\hline Valid N (list wise) & 200 & & \\
\hline
\end{tabular}

Table 1: Science Teachers' Knowledge about Nature of Science and Its Implication for Teaching

From Table 1 above, majority of the teachers appear to have varied knowledge and understanding about nature of science. Nine items were designed in the questionnaire to test the teachers' conception about the nature of science. The mean score of the first item in the questionnaire about meaning of science is 3.25. This indicates that majority of the teachers agreed that science involves firsthand experience, enquiry and problem solving which also underlie the constructivist principle of teaching science. Consistent with the majority opinion in item one, the teachers also agreed with the statement in item 9 of the questionnaire that science is a human construct with a mean score of 3.13.

With the mean score of 1.86, which is less than 2.5 ( $<2.5$ is general disagreement), it suggests that majority of the teachers disagree also with item 7 of the questionnaire that the best way to learn science is through memorization of facts and principles. This implies that most of the teachers understand that scientific knowledge is best acquired through observation, experimentation, enquiry, and problem solving. From the above, it is supposed that teachers holding this belief about nature of science are more likely to engage their students in problem solving approach to teaching.

The mean score of 2.63 and standard deviation 0.905 in the fourth item suggests that although most of the teachers agreed with the item some teachers strongly disagreed with it. Similarly the second item states that scientific knowledge and explanations in textbooks are always true. Although a large proportion of the teachers rejected this item, the mean score of 2.92 and a standard deviation of 0.808 suggest that quite some number also think otherwise. The mean scores in the fifth and eighth items suggest that the teachers perceived no contradiction in these items.

In general terms, it could be argued from these results that even though most of the teachers expressed some knowledge about the nature of science, a large number of the teachers are either naïve or not well informed about it. This result has been consistent with several other research reports which have indicated that most teachers hold naïve or inadequate science philosophy (Gallagher, 1991; Lederman, 1992, Pomeroy; 1993, Yerrick, Parke \& Nugent, 1997). Naïve epistemology indicates a positivist perspective describing scientific knowledge as true, real, and existing independently of personal experiences. Bartholomew, Osborne and Ratcliffe (2004) also share the same belief that most science teachers focus on "what we know", (thus, scientific facts), at the expense of "how we know", (thus, the Nature of science) in their teaching.

Research question 2 was on how teachers incorporate their science beliefs in science teaching in a constructivist landscape and this is presented on Table 2 . 


\begin{tabular}{|c|c|c|c|}
\hline & $\mathbf{N}$ & Mean & Std. Deviation \\
\hline 1. Teaching is the act of imparting knowledge & 200 & 3.43 & .589 \\
\hline 2. Scientific knowledge is a reflection of things around us. & 200 & 2.90 & .723 \\
\hline $\begin{array}{l}\text { 3. Laboratory work in schools is to validate concepts already } \\
\text { studied in class }\end{array}$ & 200 & 2.88 & .828 \\
\hline $\begin{array}{l}\text { 4. Different cultures have different scientific explanation for the } \\
\text { same event }\end{array}$ & 200 & 2.86 & .891 \\
\hline 5. Learning is invention rather than accumulation of facts & 200 & 2.75 & .831 \\
\hline 6. Science in schools is best taught as a set of process skills & 200 & 2.73 & .775 \\
\hline $\begin{array}{l}\text { 7. If scientists keep working, all the rules of nature will be } \\
\text { discovered }\end{array}$ & 200 & 2.70 & .881 \\
\hline $\begin{array}{c}\text { 8. Students investigating their own ideas is better than they } \\
\text { doing sets of tasks }\end{array}$ & 200 & 2.50 & .874 \\
\hline $\begin{array}{l}\text { 9. Teachers facilitate learning but students should be allowed to } \\
\text { construct their own knowledge }\end{array}$ & 200 & 2.11 & .918 \\
\hline $\begin{array}{l}\text { 10. Scientific knowledge is discovered and constructed by } \\
\text { scientists }\end{array}$ & 200 & 2.67 & .859 \\
\hline Valid N (listwise) & 200 & & \\
\hline
\end{tabular}

Table 2: Teachers' Beliefs about Science Teaching in a Constructivists Perspective

From Table 2, the teachers' belief about teaching as indicated in the first item can be classified as traditional since the mean score of 3.43 is an indication of a general agreement that teaching is the act of imparting knowledge. This view of teaching makes learners assume the role of passive recipients of knowledge which is contrary to the constructivist's principle of teaching. Constructivist learning principles assert that knowledge is not passively received but is actively constructed by the learner (Wheatley, 1991) and portray a completely different view of teaching and learning than the traditional didactic view.

The mean score of 2.11 for item 9 of the table confirms the teachers' traditional belief expressed in the first item. Majority of the teachers disagreed that students must be allowed to actively construct their own knowledge while they (the teachers) act as facilitators. The constructivist's principle also suggests that students should be active learners, questioners who are responsible for their own learning (Brooks \& Brooks, 1999).The views expressed above suggest that most of the teachers do not have adequate knowledge about how scientific knowledge is generated, even though a large number agree to item 2 that scientific knowledge is a reflection of things around us.

The response to the last item on Table 2 indicates that majority of the teachers with the mean score of 2.67 agreed that scientific knowledge is discovered and constructed by scientists.

The teachers agreed to item 5 in the table that learning is invention rather than accumulation of facts. The mean score of 2.73 also suggests the teachers agreed that science in schools is best taught as a set of process skills.

\section{Conclusions}

Based on the findings of this study, it is concluded that the teachers showed inadequate understanding of the nature and characteristics of scientific knowledge and how this knowledge is generated.

Majority of the teachers had a positive belief that science teaching takes place in a constructivist's perspective.

\section{Recommendation}

It was recommended that teacher education programs should provide teacher trainees with methodsand opportunities to learn in order to implement constructivist teaching and learning in their classrooms.

\section{References}

i. American Association for the Advancement of Science (1990). Science for All Americans: Project 2061. New York, NY: Oxford university press.

ii. Anamuah-Mensah, J., Mereku, D.K. \& Ampiah, J.G. (2009). TIMSS 2007 Ghana Report: Findings from IEA's trends in international mathematics and science study at the eighth grade. Accra: Adwinsa Publications (Gh) Ltd

iii. Anamuah-Mensah, J., Buckler, A., Moon, B., Ricketts, K. \& Wolfenden, F. (2008). Building an effective 'Open Education Resource' (OER) Environment for Teacher Education in Sub-Saharan Africa: The TESSA Experience. A paper presented at PCF4, University of London.

iv. Anamuah-Mensah, J., Mereku, D. K. and Asabere-Ameyaw, A. (2004) Ghanaian Junior Secondary School Students' Achievement in Mathematics and Science: Results from Ghana's participation in the 2003 Trends in International Mathematics and Science Study, Accra: Ministry of Education Youth and Sports

v. Anderson, I. K. (2006). Relevance of Science Education: As seen by GhanaianJuniorSecondary School Student. Unpublished Ph.D. Thesis, South Africa: University of theWestern Cape. 
vi. Bartholomew, H., Osborne, J. \& Ratcliffe, M. (2004). Teaching students "ideas about science":five dimensions of effective practice. Science Education,88, p. 655682.

vii. Brooks, J. G., \& Brooks, M. G. (1999). In search of understanding: The case for constructivist classrooms. Alexandria, VA: Association for Supervision and Curriculum Development

viii. Burnie, D. (2008) "Science." Microsoft Student 2009 [DVD]. Redmond, WA: Microsoft Corporation.

ix. Fredua- Kwarteng, Y. and Ahia, F. (2005, January 08). Ghana Flunks at Maths and Science: analysis (1). Retrieved November 15, 2010. From ghanaweb.com.

x. Gallagher, J.J. (1991). Prospective and practicing secondary school science teachers' knowledge and beliefs about the philosophy of science. Science Education, 75, 121-133

xi. Iqbal, H. M. (1998). Science Graduates`Understanding of science process skills. Science Education international, 9(2), 23-27

xii. Lederman, N. G. (1992). Students' and teachers' conceptions of the nature of science: A review of the research. Journal of Research in Science Teaching, 29(4), 331-359

xiii. Pomeroy, D. (1993). Implications of teachers' beliefs about the nature of science: Comparison of the beliefs of scientists, secondary science teachers, and elementary teachers. Science Education, 77(3), 261- 278

xiv. National Research Council, (1996). National science education standards. Washington,DC: National Academy Press.

xv. UNESCO (2005). Education for all. The quality imperative. Paris: UNESCO

xvi. West Africa Examination Council (2005). Chief Examiners' Report on Basic Education Certificate Examination. Accra: Wisdom Press.

xvii. West Africa Examination Council (2006). Chief Examiners' Report on Basic Education Certificate Examination. Accra: Wisdom Press

xviii. West Africa Examination Council (2007). Chief Examiners' Report on Basic Education Certificate Examination. Accra: Wisdom Press.

xix. West Africa Examination Council (2008). Chief Examiners' Report on Basic Education Certificate Examination. Accra: Wisdom Press

xx. Wheatley, G. H. (1991). Constructivist perspectives on science and mathematics learning. Science Education, 75(1), 921.

xxi. Yerrick, R., Parke, H., \& Nugent, J. (1997). Struggling to promote deeply rooted change: the "filtering effect" of teachers' beliefs on understanding transformational views of teaching science. Science Education, 81, 137-159 